\title{
Determining Cognitive Structures and Alternative Conceptions on the Concept of Reproduction (The Case of Pre-Service Biology Teachers)
}

\author{
Hakan Kurt ${ }^{1 *}$, Gülay Ekici ${ }^{2}$, Özlem Aksu ${ }^{3}$, Murat Aktaş ${ }^{4}$ \\ ${ }^{1}$ Department of Biology Education, Necmettin Erbakan University, Konya, Turkey \\ ${ }^{2}$ Department of Educational Sciences, Gazi University, Ankara, Turkey \\ ${ }^{3}$ Kazan Mustafa Hakan Güvençer Anatolian High School, Ankara, Turkey \\ ${ }^{4}$ Mehmet Tunç Science Education Institutes, Ankara, Turkey \\ Email: "kurthakan1@gmail.com
}

Received July 23 $3^{\text {rd }}, 2013$; revised August $23^{\text {rd }}, 2013$; accepted August $30^{\text {th }}, 2013$

Copyright (C) 2013 Hakan Kurt et al. This is an open access article distributed under the Creative Commons Attribution License, which permits unrestricted use, distribution, and reproduction in any medium, provided the original work is properly cited.

\begin{abstract}
Reproduction is among basic functions of living beings and one of elementary complex subjects of the biology course. This is complicated for learners to construct cognitive structures on the subject. The aim of the current study is to investigate pre-service biology teachers' cognitive structures related to "reproduction" through the free word-association test and the drawing-writing technique. As the research design of the study, the qualitative research method was applied. The data were collected from pre-service biology teachers. The free word-association test and the drawing-writing technique were used as data collection instruments. The data were subject to content analysis and divided into categories through coding. With the help of these categories, the cognitive structures of pre-service biology teachers were explained. The data collected through the study were divided into 7 categories (structures required for reproduction, reproduction in plants and sections, types of reproduction, insemination, reproduction-inheritance, defining reproduction and its importance, reproductive anatomy). In the categories obtained, it was determined that ample data could be collected using different assessment instruments. On the other hand, it was determined that pre-service biology teachers had alternative conceptions related to reproduction. It was observed that the pre-service teachers had imperfect cognitive structures regarding the subject of reproduction. Comprehensive suggestions related to the subject are presented at the end of this article.
\end{abstract}

Keywords: Reproduction; Cognitive Structure; Alternative Concepts

\section{Introduction}

One of the common basic functions of living organisms is "REPRODUCTION". Plants, animals and single-cell organisms reproduce, although they do this in different forms.

The subject of reproduction is covered in many different courses throughout the education life; however, biology is among those in which it is covered most. Researches show that students fail to adequately comprehend the subject of reproduction, that they fail to address the subject in its complexity by linking micro and macro levels (Hmelo-Silver \& Azevedo, 2006; Inagaki \& Hatano, 2002; Inagaki \& Hatano, 2006), that thus students cannot form their cognitive structures, that they cannot concretize abstract aspects inherent in the subject and that they fail to link the subject with their daily lives (Bahar, Johnstone \& Hansell, 1999; Cimer, 2012; Jones \& Rua, 2006; Lazarowitz \& Penso, 1992; Lewis, Leach, \& Wood-Robinson, 2000a, 2000b; Lukin, 2013; Prokop, Prokop, \& Tunnicliffe, 2007; Prokop, Prokop, Tunnicliffe, \& Diran, 2007; Seymour \& Longdon, 1991; Simpson \& Marek, 1988; Udovic et al., 2002; Tekkaya, Ozkan, \& Sungur, 2001; Treagust, 1988). One of the

\footnotetext{
"Corresponding author.
}

main reasons of the above finding is that the subject of reproduction is highly comprehensive at the micro level; and especially the subjects of growth, development, hormones, Mendel's laws, genes, chromosomes, and mitotic and meiotic division differ by species (Krawczyk, 2007; Sinan \& Karadeniz, 2010; Wynne, Stewart, \& Passmore, 2001). Therefore, construction of cognitive structure is negative affected by abstract natures of these subjects (Knippels, Waarlo, \& Boersma, 2005; Krawczyk, 2007; Smith, 1991; Quinn, Pegg, \& Panizzon, 2009).

There is a lack of consensus in the literature on how conceptual change happens while the cognitive structure is constructed (Chi, Slotta, \& Leeuw, 1994; Franco et al., 1999; Vosniadou \& Brewer, 1992, 1994a, 1994b; Vygotsky, 1995b). However, there exists a consensus that students experience difficulties when constructing their cognitive structures about concepts (Dagher, 1994; diSessa \& Sherin, 1998; Duit et al., 1998; Siegler, 1995; Stavridou \& Solomonidou, 1998; Tyson et al., 1997; Vosniadou, 1996). The inability to form the cognitive structure stems from students' inability to associate the conceptual structures pertaining to the subject with one another in their minds. It is highly difficult to explain the cognitive structures that emerge in individuals' minds after the process of learning. However; 
important relevant data can be collected by revealing learners' opinions on certain key concepts (Gilbert, Boulter, \& Rutherford, 1998a; Gilbert, Boulter, \& Rutherford, 1998b; Gilbert \& Boulter, 2000). Because researches on concepts unveil individuals' cognitive structures related to those concepts, conceptual knowledge is not only to know the name or definition of a concept, but also is to be able to see the transitions and relations between concepts. Biology is a course which requires students to be able to see the micro and macro relations among concepts. Otherwise, learning cannot be realized. At this point, teachers should guide students to improve their meaningful learning. To this end, the teacher must know students' prior knowledge (Pines \& West, 1986; Tsai \& Huang, 2001; Tsai \& Huang, 2002). This obtained information not only helps teachers develop their teaching strategies but also helps to do researches on students' conceptual changes. For incorrect prior knowledge always negatively affects learning (CUSE, 1997; Posner et al., 1982; Wandersee, Mintzes, \& Novak, 1994), and thus necessary steps need to be taken in order to alter incorrect knowledge and replace them with new ones.

While various methods are employed in order to determine conceptual learning, especially those techniques labeled as alternative measurement and evaluation techniques are frequently used. These techniques are employed not only to determine students' knowledge; but also to determine the relations that students establish between concepts, students' cognitive structures, whether they manage to accomplish meaningful learning by linking existing knowledge with new information, the extents to which they make sense of the operation of events in the natural life by associating them with their conceptual knowledge, and alternative conceptions they develop (Bahar, 2003; Bahar et al., 2006; Ercan, Tasdere, \& Ercan, 2010; Kurt, 2013). In this respect, in order to determine the cognitive structures and alternative conceptions related to the concept of reproduction; two-step multiple-choice tests (Odom \& Barrow, 1995; Tekkaya, 2003), drawings (Ainsworth, Prain, \& Tytler, 2011; Cetin et al., 2013; Cinici, 2013; Nyachwayaa et al., 2011; Patrick \& Tunnicliffe, 2010; She, 2004; Yayla \& Eyceyurt, 2011; Zoldosova \& Prokop 2007), interviews (Kose, 2008), independent word association test (Ad \& Demirci, 2012; Dove, Everett, \& Preece, 1999; Ercan \& Tasdere, 2010; Koseoglu \& Bayir, 2011; Kurt, 2013), structured grid, diagnostic tree, concept maps, conceptual change texts, analogy, prediction-observation-explanation and other techniques can be used (Bahar et al., 2008; White \& Gunstone, 1992). In this research, the independent word association test and drawing-writing technique were employed.

These measurement techniques listed above are employed both in determining the scientific cognitive structures about concepts that students are supposed to have and in the nonscientific cognitive structures that students are not supposed to have. During the process of learning, individuals may incorporate non-scientific concepts along with scientific ones into their cognitive structures. There are different terms used in the literature for conceptual structures that are scientifically incorrect or that contradict scientific facts. "Misconception", "preconception", "alternative frameworks" and "alternative conception" (Doran, 1972; Driver \& Easley, 1978; Driver, 1989; Mike \& Treagust, 1998; Skelly \& Hall, 1993; Smith, Blakeslee, \& Anderson, 1993) are among these terms. In this study, the term "alternative conception" was used. Alternative conceptions are not preferred in learning and teachers try to keep them at the lowest level possible, because alternative conceptions may direct students to incorrect conclusions while learning negatively affect their accurate construction of new information in their minds (Albanese \& Vicentini, 1997; Tsai, 1999).

\section{Conceptual Structure Researches in the Literature on the Concept of Reproduction}

Researches on the subject of reproduction in the literature have been carried out both at different scientific dimensions, and with the participation of students from different levels of study and with participants from different segments of the society. For the subject of reproduction is pertinent to people from all walks of life. On the other hand, since the subject of reproduction is linked with many different subjects in curricula such as growth, development, hormones, genetic, chromosomes, mitotic and meiotic division; it was determined that studies conducted with students have addressed different subjects and different species. However, it was observed that only the subject of reproduction in humans has been addressed in studies carried out with participants from different segments of the society.

In studies conducted with the participation of students; In studies conducted with students aged $14-16$; the subjects of comparing genetic knowledge and chromosome number in an original and new cell, defining the place in human body where cell division occurs, and stating the same cell division occurs in plants were presented on the subject of "cell division"; and the subjects of comparing chromosome numbers in egg and sperm cells, determining the chromosome number in a fertilized egg, explaining the purposes of sexual reproduction, and specifying the types of reproduction in plants were presented on the subject of "fertilization" (Lewis, Leach, \& Wood-Robinson, 2000a 2000b, 2000c).

Akyurek and Afacan (2012) determined that 8th grade students have alternative conceptions regarding the concepts of "chromosome", "gene", "meiotic division", "mutation", "mitotic division", "modification" and "DNA"; whereas Robinson and Lewis (2000) carried out a similar study with 16-year-old students and found that they failed to comprehend the subject of "genetic transfer (transduction)" and that they had imperfect knowledge about "genes", "chromosomes" and "cells".

Emre and Bahsi (2006) found that pre-service science teachers have misconceptions about the subject of cell division, whereas Tekkaya, Capa and Yilmaz (2000) determined that pre-service biology teachers misunderstood various important concepts such as gene, allele, homologous chromosome, replicated chromosome, chromosome number and DNA strand, and that they have misconceptions. Atilboz (2004) found that students mostly experience difficulty in comprehending, and have misconceptions about, chromosome-DNA relationship, chromosome structure of cells that emerge as a result of mitotic and meiotic division, the concept of diploid-haploid cell, number of cells produced by mitotic and meiotic division, homologous chromosome, sister chromatids, and events happening during mitotic and meiotic division.

Sesli and Kara (2012) determined high school students' alternative conceptions about the subjects of cell division and reproduction. They found the following alternative conceptions: "daughter cells contain more genetic knowledge and chromosomes than mother cells", "following any kind of a division, daughter cells have half the number of chromosomes that the 
mother cell has", "cells of the same species have the same genetic data", "genetic knowledge is universal and unchangedable", "cell division does not occur in testicles and eggs, because they are haploids", "since plant and animal cells are different, plant cells cannot execute cell division", "number of chromosomes will rise faster after the division, because more cells will be formed", "cells with the same chromosome numbers have the same genetic data", "meiosis occurs in our bodies both in somatic cells and gametes", "while animals sexually reproduce, plants asexually reproduce", "sperm cells may be different from egg cells due to the possibility of having $X$ and $Y$ chromosomes", "egg cells are the same since they emerge from the same mother cell", "sperm and egg cells have the same chromosome number since they have the same gametes", "zygotes may vary through matching of big and small cells", "an egg cannot reach the adequate number of chromosomes for an organism", "primitive species reproduce only asexually", "there is no genetic difference between single-cell organisms", "prokaryotes reproduce through mitotic division", "prokaryotes cannot sexually reproduce as they do not have sexes", "plants cannot sexually reproduce since they cannot move and their sexual organs are not developed", "plants cannot sexually reproduce as they do not have sexes".

Mak, Yip and Chung (1999) determined that a great majority of pre-service teachers have the alternative conceptions that "ovule of flower develops in the seed's embryo following pollination", "an apple grows out of the ovary of flower", "fruit grows from flower's receptacle" and "pollen grains are male gametes of flowery plants". On the other hand, Bebbington (2005) suggests that students are incompetent in categorizing and naming plants, whereas Hershey (2004) determined that students tend to think of pollination only linked with animals, that there exists a widespread confusion between pollination and insemination, and that students have imperfect and incurrect knowledge especially about how plants reproduce. In this respect, Hershey brought students' alternative conceptions regarding plants under five different groups: "oversimplifications", "overgeneralizations", "obsolete concepts and terms", "misidentifications" and "flawed research". Yip (1998) determined children's misconceptions about reproduction and provided teaching-related suggestions.

Cinici (2013) investigated high school students' opinions on the life form and cycle of the butterfly with respect to reproduction using open-ended questions and drawing. Students' drawings were grouped under five categories after coding the frequencies and frames of drawings of external organs, and it was found that students have imperfect and incorrect knowledge.

Schussler (2008) located misconceptions about reproduction and the concepts of plant, flower and fruit in children's books.

In studies conducted with the participation of individuals from different segments of the society; Iliyasu et al. (2012) investigated girls' relationships with their mothers in terms of sexual and reproductive health. They found that most girls learn these issues from their mothers, as they mostly talk about marriage, menstruation, flirtation, premarital sex and sexually transmitted diseases. The authors suggested that the quality and scope of mothers' domestic reproductive health training in Northern Nigeria should be improved.

When doctors' levels of knowledge about issues pertaining to reproductive health such as safe motherhood, emergency obstetric care, family planning, sexually transmitted diseases (STDs) and reproductive health services for the young; it was found that the level of knowledge in safe motherhood is low, in emergency obstetric care is high, in family planning is high, in STDs is high, and in reproductive health services for the young is high.

Warenius et al. (2007), in the study carried out with seconddary school students, determined alternative conceptions such as contraceptive pills and condoms used for cancer. Amuyunzu-Nyamongo et al. (2005) determined that young people have very strong doubts about condoms as a method that prevents HIV and pregnancy that their primary sources of information on sexuality are their friends and yellow press; however, they prefer to get information from professional health workers.

Ugoji (2013) indicates that there exists no statistically significant correlation between university students' knowledge of reproductive health, their concept structures and locus of controls; and argues that imperfect and incorrect prior knowledge can be prevented by adequately covering these issues in curricula.

Studies on the subject demonstrate that the concept of reproduction requires a highly wide perspective as it is a subject that pertains to numerous fields other than the scientific-academic field such as social, economic, political, and ethical and health fields. For this reason, biology teachers are assigned in the society with a serious responsibility. Therefore, it is believed that findings to be obtained by determining the cognitive structures of biology teacher candidates, who will be biology teachers in the future, on the subject of reproduction, will be of high importance.

Considering the limitations of the study, we attempted to decrease these limitations. The main reason for these limitations is its being a qualitative study (Gall et al., 2002; Hitchcock \& Hughes, 1995; Miles \& Huberman, 1994; Verma \& Mallick, 1999). The study group was chosen through purposeful sampling for the accessibility of the participants (Given, 2008; Knight et al., 2013; Patton, 1990). All the questions and concerns of the participants were answered, and the answers of the participants were given with the participant numbers without any change (Cohen \& Manion, 1997; Kus, 2003; Patton, 1990; Punch, 2005). According to the views of the specialists in the field, the reliability analyses were carried out, and the data were collected under the categories.

The aim of this study is to determine pre-service biology teachers' cognitive structures on the concept of "reproduction" by using the techniques of independent word association and drawing-writing. To this aim, answers were sought to the following questions:

1) What cognitive structures do pre-service biology teachers have, according to the independent word association test, on the concept of reproduction?

2) What cognitive structures do pre-service biology teachers have, according to the drawing-writing technique, on the concept of reproduction?

3) What are the alternative conceptions of pre-service boilogy teachers on the concept of reproduction?

In line with the suggestions above, the cognitive structures of reproduction were determined for student teachers. After reviewing the data with the techniques of free association test and drawing-writing technique, some alternative concepts were created with each technique. Figure 1 was created based on the cognitive structures of Biology student teachers about reproduction. At the last section, the data obtained from the study were discussed with the previous literature, and some sugges- 


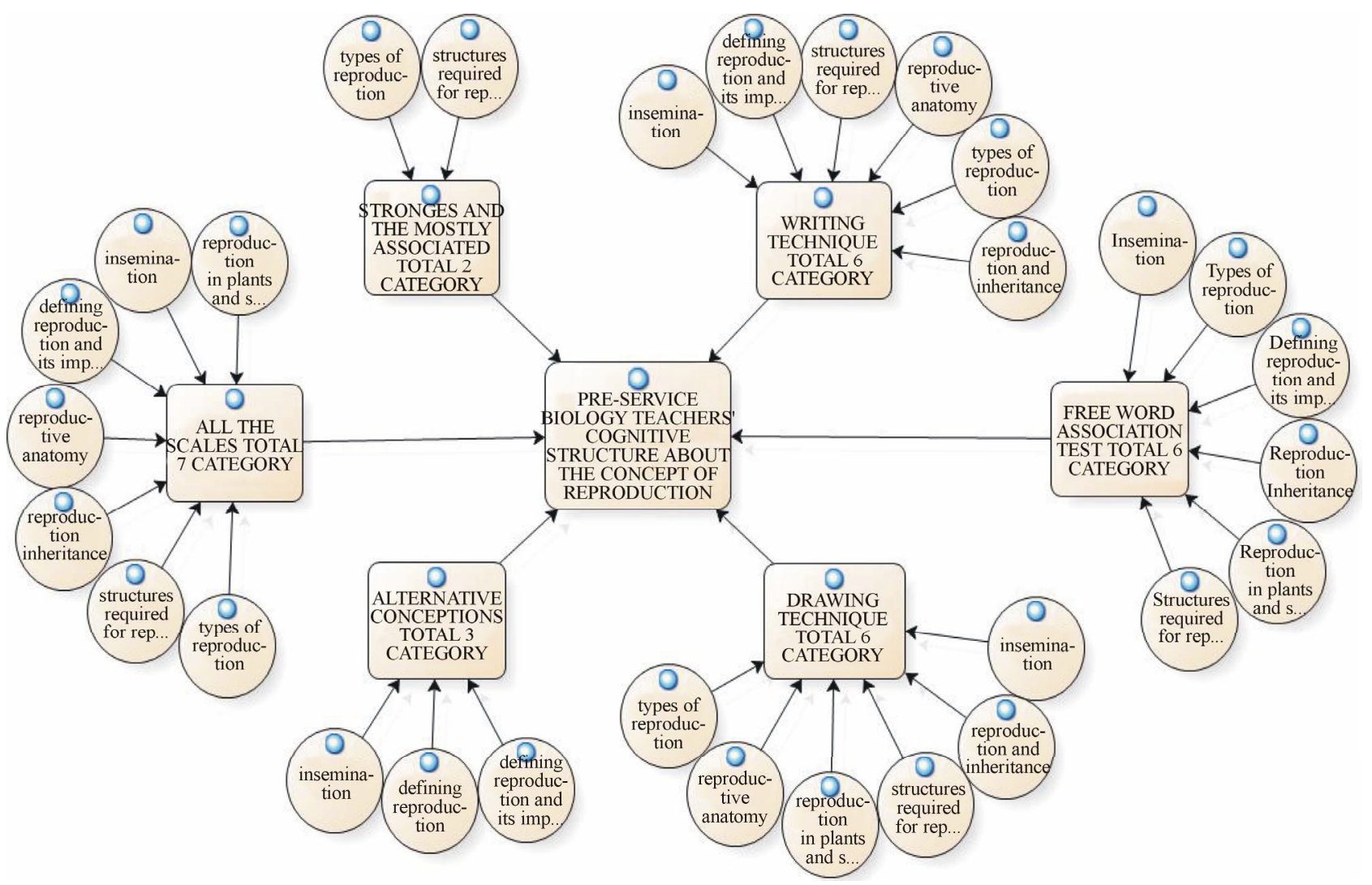

Figure 1.

Cognitive structures of pre-service biology teachers about reproduction.

tions were presented.

\section{Methodology}

In this research, the qualitative research method was employed. Examination of different aspects of education through the qualitative research method has been a very widespread approach especially in the last 20 years (Gall et al., 2002; Hitchcock \& Hughes, 1995; Miles \& Huberman, 1994; Verma $\&$ Mallick, 1999). A qualitative research approaches the subject with an interpretative and natural perspective and focuses on more than one method. The main purpose in such researches is to present the subject in a detailed and realistic manner. Therefore, it is of importance to present the data as detailed and direct as possible (Cohen \& Manion, 1997; Kus, 2003; Patton, 1990; Punch, 2005). The qualitative research method was preferred in this study, since the cognitive structures of pre-service biology teachers are presented in detail using the independent word association test and the drawing-writing technique in this research.

\section{Study Group}

A total of 44 fourth and fifth year Biology teaching students from Necmettin Erbakan University participated in this study, which was carried out in the 2011-2012 Academic Year. Of the participants, $35(79.5 \%)$ are females, and $9(20.5 \%)$ are males. In addition, 19 of the participants $(43.20 \%)$ are 4 th year students, and $25(56.80 \%)$ are 5 th year students. This study benefited from purposive sampling. Some criteria were taken into consideration in order to minimize the problems in purposive sampling (Given, 2008; Knight et al., 2013; Patton, 1990). In this vein, several criteria were taken into consideration while selecting the participants such as having completed the field courses in biology, willingness to participate in the study, being seniors in the department of biology teaching and having completed the courses, and being available to the researcher.

\section{Data Collection Instruments}

Using independent word association test and drawing-writing technique in this research as data collection instruments, it was aimed to collect detailed information regarding pre-service Biology teachers' conceptual structures on the concept of "reproduction". Information on these assessment instruments is given below:

Free Word Association Test: This technique, which is based on the assumption of giving responses to independent stimulant words without limiting the ideas coming to the mind (Bahar, Johnstone, \& Sutcliffe, 1999; Sato \& James, 1999), is one of the oldest methods and has been used in numerous researches (Ad \& Demirci, 2012; Bahar \& Kilicli, 2001; Bahar \& Ozatli, 2003; Cardellini \& Bahar, 2000; Daskolia, Flogaitis, \& Papageorgiou, 2006; Dove, Everett, \& Preece, 1999; Hovardas \& Korfiatis, 2006; Isikli, Tasdere, \& Goz, 2011; Wagner, Valencia, \& Elejabarrieta, 1996). It is among the most widely used techniques with the purpose of determining individuals' cognitive structures about concepts, analyzing the links between concepts in these structures, and whether the links between concepts in individuals' long-term memories are adequate or 
not. In this research, the concept of "reproduction" was selected as the stimulant for the word association test, and presented to the participants in the following format. Figure 2 shows an example response given by a participant (P27) in the word association test.

\section{KEY CONCEPT: REPRODUCTION}

Reproduction 1:....

Reproduction 2:...................

.

Reproduction 10: SENTENCE:

As is seen in the Figure 2, the word association test consists of two stages.

At the first stage; participants are required to write down the concepts that the stimulant word has brought to their minds in a given duration 40 seconds in this research (Gussarsky \& Gorodetsky, 1990). The pre-service biology teachers were asked to write down the first ten words that come to their mind first, when they see or hear the word "reproduction" in 40 seconds. The reason the key concept was written more than once is to avoid the risk of chain responses, because otherwise the student might write down concepts that her previous responses bring to her mind instead of the key concept. Such a situation harms the objective of the test.

At the second stage; participants are required to write down sentences in 20 seconds about the key concept. These sentences were analyzed one by one during the analysis of data, because the response sentence that is associated with the key concept may be a product of evocation that is not significantly correlated with the key concept. Besides, since a sentence is much more complex and advanced than a single word, the evaluation process is influenced by situations whether the sentence is scientific or not, or whether it involves misconceptions or not.

Drawing-Writing Technigue: This technique has been used in numerous scientific researches (Cetin et al., 2013; Nyachwayaa et al., 2011; Pluhar et al., 2009; Prokop, Fancóvicóva, \& Tunnicliffe, 2009; Shepardson et al., 2007; Stafstrom, 2002; Yayla \& Eyceyurt, 2011; Yorek, Sahin, \& Ugulu, 2010). It was aimed with the drawing-writing technique to thoroughly examine pre-service teachers' opinions on the concept of reproduction (Rennie \& Jarvis, 1995), because this technique is highly effective in obtaining natural and high-quality data about hidden opinions, understandings and attitudes regarding these technical concepts (Backett-Milburn \& Mckie, 1999; Pridmore \& Bendelow, 1995; White \& Gunstone, 1992). In this respect, the participants were asked to freely state their opinions answering the question "Express what you know about the concept of reproduction with figures" in five minutes. Below is an example of students' response papers (Figure 3).

\section{Analysis of Data}

Before starting to analyze the data, the participants' response papers were assigned numbers from 1 to 44 in order to show whom the response belongs to. The data, obtained using the two assessment instruments, were analyzed based on the content analysis method. The main purpose in this method is to obtain concepts and relations that can explain data. For this purpose, similar data were brought together under certain concepts and themes, and they were organized in a way the reader

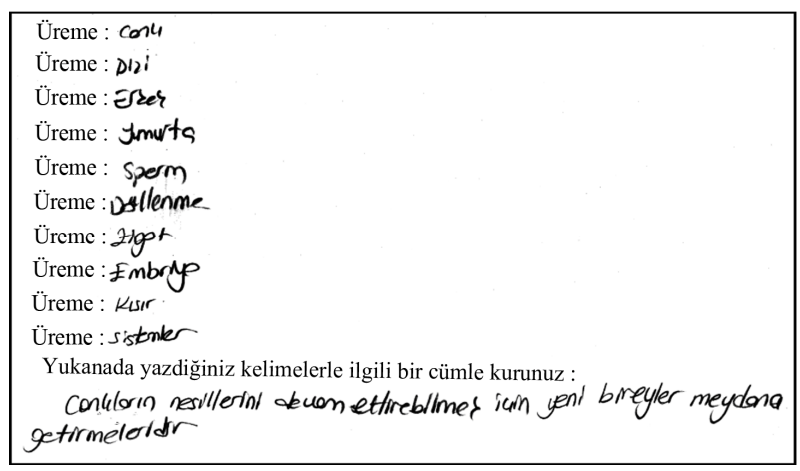

Words in the answer sheet: Reproduction 1: Living-Thing. Reproduction 2 Female. Reproduction 3: Male. Reproduction 4: Egg. Reproduction 5: Sperm. Reproduction 6: Insemination. Reproduction 7: Zygote. Reproduction 8: Embryo. Reproduction 9: Infertile. Reproduction 10: Systems. Sentence in the answer sheet: It is production of a new individual by living beings to be able to continue their species.

Figure 2.

P27's response paper.

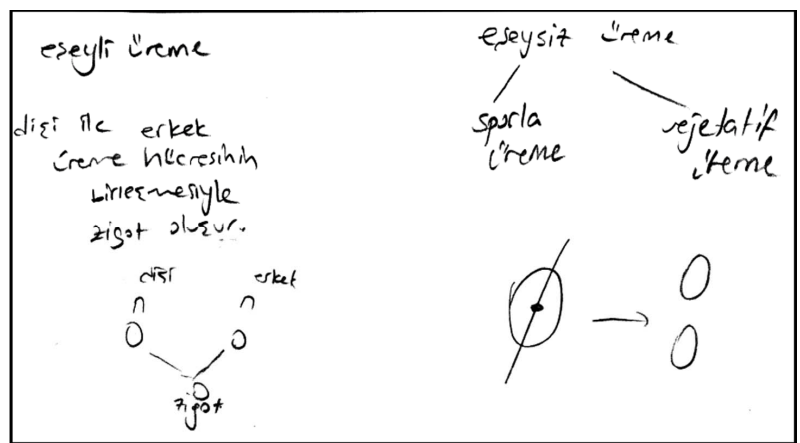

The participant drawing $(P 25)$ depicting how reproduction is. The participant mentions, "Sexual reproduction, asexual reproduction, vegetative reproduction, spore reproduction. Zygote is formed after the female and male reproductive cells are matched".

\section{Figure 3.}

P25's response paper.

can understand. In this framework, the data were assessed according to their frequency values.

The data obtained from the independent word association test were analyzed using the techniques of number of words, number of responses and semantic relation (Atasoy, 2004; Shavelson, 1974). Words with the same meaning were grouped under words recurred most frequently. Words, which were regarded as irrelevant, which were not associated with other words, and which were stated only for once were excluded from the analysis. Words were categorized by using semantic relation criteria, and frequencies of words in each category were calculated. Many studies show that this type of data analysis produces reliable results (Daskolia, Flogaitis, \& Papageorgiou, 2006; Hovardas \& Korfiatis 2006; Kostova \& Radoynovska, 2008; Kostova \& Radoynovska, 2010; Kurt, 2013; Wagner, Valencia, \& Elejabarrieta, 1996; White \& Gunstone, 1992).

In the drawing-writing technique, on the other hand, drawing-writing data regarding the concept of reproduction were analyzed using the content analysis method. By means of the drawing task, the students' ideas about reproduction were investigated, not the ability to draw it, so the precision in shape was ignored. It was a struggle to provide a scoring scale which gave minimum credit to the artistic quality of the drawing 
(Reiss et al., 2002). First, the participants' drawings related to the concept of reproduction were grouped under certain categories and sub-categories. Then, the cognitive structures demonstrated by the participants on the concept of reproduction were analyzed with respect to their levels. While determining these levels, data are grouped from level 1 to level 5 (Bahar et al., 2008; Bartoszeck, Machado, \& Amann-Gainotti, 2008; Cinici, 2013; Reiss \& Tunnicliffe, 2001). The level groups, which were formed with the purpose of evaluating participants' cognitive structures on the concept of reproduction through their drawings, are presented in Table $\mathbf{1}$.

Moreover, both in the independent word association test and in the drawing-writing technique, the explanations provided by the participants for the concept of reproduction within texts are presented in quotation marks in the following form: [“..." (P11)]. In the drawing-writing technique, examples from participants' drawings are presented with respect to categories by indicating the number assigned to the participants (e.g. P19 or P23).

Validity and reliability are among the most important issues for qualitative researches. In the research, two important processes were executed in order to ensure the validity of results: 1) Detailed explanations were provided on the processes of encoding data and analyzing data (how the conceptual category was reached) (Hruschka et al., 2004; Daymon \& Holloway, 2003); 2) For each of the categories obtained in the research, an example response, which was thought to represent that category best, was assigned and presented in the "Findings" section (Roberts \& Priest, 2006; Wiersma \& Jurs, 2005).

In order to ensure the reliability of the research, on the other hand, codes and categories pertaining codes, which were produced by two researchers, were compared with the purpose of checking whether the codes given under the conceptual categories represent these conceptual categories or not. After the research data were encoded separately by two biology experts, the researcher gave these lists of codes and themes their final forms. Consistency between the codes used independently by the researchers was determined by marking them as "Agreement" (when they used the same code for students' responses) or "Disagreement" (when they used different codes). In cases when a researcher ran into a contradiction, encoding was performed by taking the opinion of the other researcher. The reliability of the data analysis conducted in the above-explained manner was calculated using the following formula: [Agreement/(Agreement + Disagreement $) \times 100]($ Miles \& Huberman, 1994). The mean reliability between the encoders was found at $96 \%$. Besides, in order to improve the validity and reliability of the research, data diversification was performed by collecting data using different instruments.

On the other hand, NVivo9.3 software was used in forming the Figure 1 on students' cognitive structures about reproduction.

\section{Findings}

In this section, findings are divided into two according to the method. Then, alternative conceptions of participants on the subject of reproduction, which were determined through both methods, will be presented.

\section{Findings Obtained from Free Word Association Test}

As a result of the analysis of participants' cognitive structures regarding the concept of reproduction, a total of six categories were formed. These categories and words given under them were listed and their frequency values were provided (Daskolia et al., 2006; Kostova \& Radoynovska, 2008; Kostova \& Radoynovska, 2010; Kurt, 2013; Torkar \& Bajd, 2006; Wagner et al., 1996; White \& Gunstone, 1992). Words presented only for once (95 words [22.83\%]) were excluded from the analysis. These words are presented in the comments section at the end of each category. As a result, the remaining 46 different words were divided into six categories. Table 2 shows these words and categories. 321 words were received in total.

In the analysis of the data obtained, most of pre-service teachers' responses went under the category of "structures required for reproduction", which thus emerged as the dominant category $(f=153)$. While in this category most of the participants emphasized on the words "sperm", "egg", "ovary", "spore", "vagina", "uterus", "testicle" "male", "female", "womb", "penis", "male reproductive system", "female reproductive system" and "hormone", some others wrote the words "scrotum", "sex" and "oviduct". The words that were written in this category only for once by the participants and thus were excluded are the following: "sexual glands" and "sperm tube". These results indicate that the participants mostly associate their cognitive structures about the concept of reproduction with concepts under the category of "structures required for reproduction". Moreover, it was observed that reproduction mostly meant "reproduction in humans" to the participants as they rarely thought about concepts related to reproduction of other species. This shows that the dimensions of the participants' cognitive structures on reproduction are limited.

In the second category, participants presented associations related to "reproduction in plants and sections" $(\mathrm{f}=41)$. While most participants wrote the words "ovary", "gamete", "pollen", "pollination" and "fallopian tube", a lesser number of participants wrote "seed" and "flower". Some of the words that were written in this category only for once by the participants and thus were excluded are the following: "anther", "germination", "bridging", "insemination pipe", "insemination tube", "follicle tubes", ovule", "oocyst", "pollen tubes", "stigma", "sprout" and "diaspore".

The third category was "types of reproduction" ( $\mathrm{f}=39)$.

Table 1.

Level groups formed to evaluate participants' cognitive structures on reproduction through their drawings.

\begin{tabular}{cr}
\hline Levels & Drawings \\
\hline Level 1 & No drawing \\
Level 2 & Non-representational-carton drawings (drawings related to one or two dimensions of the concept) \\
Level 3 & Drawings with alternative concepts (drawings that are related to two or three dimensions of the concept and that include alternative conceptions) \\
Level 4 & Partially correct drawings (drawings that are related to three or more dimensions of the concept but that include imperfect knowledge) \\
Level 5 & Comprehensive representation drawings (comprehensive drawings that are related to three or more dimensions of the concept) \\
\hline
\end{tabular}




\section{H. KURT ET AL.}

Table 2.

Distribution of pre-service biology teachers' cognitive structures about "reproduction" by categories.

\begin{tabular}{|c|c|c|}
\hline Categories & Concepts under categories and their frequencies & Total frequencies of categories \\
\hline \multirow{17}{*}{ 1. Structures required for reproduction } & "sperm" (29) & \multirow{17}{*}{153} \\
\hline & “egg” (19) & \\
\hline & “ovary” (14) & \\
\hline & "spore" (12) & \\
\hline & "vagina" (11) & \\
\hline & "uterus" (10) & \\
\hline & "testicle" (9) & \\
\hline & "male" (9) & \\
\hline & "female" (8) & \\
\hline & "womb" (7) & \\
\hline & "penis" (6) & \\
\hline & "male reproductive system" (4) & \\
\hline & "hormone" (4) & \\
\hline & "female reproductive system" (4) & \\
\hline & "scrotum" (3) & \\
\hline & “sex" (2) & \\
\hline & "oviduct" (uterine tube) (2) & \\
\hline \multirow{7}{*}{ 2. Reproduction in plants and sections } & “ovary” (10) & \multirow{7}{*}{41} \\
\hline & "gamete" (9) & \\
\hline & “pollen” (8) & \\
\hline & "Pollination" (5) & \\
\hline & "fallopian tube" (4) & \\
\hline & “seed" (3) & \\
\hline & "flower" (2) & \\
\hline \multirow{6}{*}{ 3. Types of reproduction } & "sexual reproduction" (14) & \multirow{6}{*}{39} \\
\hline & "asexual reproduction" (13) & \\
\hline & “conjugation" (5) & \\
\hline & "spermatogenesis" (3) & \\
\hline & "vegetative" (2) & \\
\hline & "parthenogenesis" (2) & \\
\hline \multirow{5}{*}{ 4. Insemination } & "zygote" (13) & \multirow{5}{*}{35} \\
\hline & “insemination" (12) & \\
\hline & "embryo" (6) & \\
\hline & "fetus" (2) & \\
\hline & "blastula" (2) & \\
\hline \multirow{6}{*}{ 5. Reproduction-Inheritance } & "meiosis" (16) & \multirow{6}{*}{35} \\
\hline & "mitosis" (11) & \\
\hline & "chromosome" (2) & \\
\hline & "division" (2) & \\
\hline & “cross-over” (2) & \\
\hline & “diversity" (2) & \\
\hline \multirow{5}{*}{ 6. Defining reproduction and its importance } & "proliferation" (5) & \multirow{5}{*}{18} \\
\hline & “copulation” (4) & \\
\hline & "continuation of generation" (3) & \\
\hline & "new individual" (3) & \\
\hline & "continuity" (3) & \\
\hline Total & 46 words & 321 \\
\hline
\end{tabular}


While most of the participants wrote "sexual reproduction", "asexual reproduction" and "conjugation", some others wrote "spermatogenesis", "vegetative", and "parthenogenesis". The words "amitosis", "oogamy", "oogenesis", "metagenesis" and "cloning" were excluded from this category.

In the fourth category, participants presented associations related to "insemination" ( $\mathrm{f}=35)$. They mostly focused on the words "zygote", "insemination" and "embryo" in this category, whereas a very limited number of them wrote "fetus" and blastula". The words "semen", "sperm alternation", "morula" and gastrula" were written for once and thus excluded from analysis.

In the fifth category, participants presented associations related to "reproduction-inheritance" ( $\mathrm{f}=35$ ). While most of them focused on the words "meiosis" and "mitosis", a lesser number wrote "chromosome", "division", "crossover" and "diversity". The words that were written in this category only for once by the participants and thus were excluded are the following: "DNA", "gene", "genetics", "genetic data", "homologous chromosome", "meiosis-1", "meiosis-2" ,"metaphase", "prophase", "chromosome", "recessive", "infertile", "transfer" and "mutation".

The sixth category, finally, consisted of associations related to "defining reproduction and its importance" $(\mathrm{f}=18)$. While the participants mostly presented the words "proliferation" and "copulation", a lesser number of them wrote "continuation of generation", "new individual" and "continuity".

\section{Findings Obtained from the Drawing-Writing Technique}

The drawing-writing technique produced six categories. The following categories were produced in the drawing technique: structures required for reproduction (43), insemination (31), types of reproduction (17), reproduction and inheritance (12), reproduction in plants and sections (7) and reproductive anatomy (4); whereas the following categories were produced in the writing technique: types of reproduction (18), reproduction and inheritance (8), defining reproduction and its importance (8), structures required for reproduction (6), insemination (6) and reproductive anatomy (4) (Table 3 ).

It was observed that the pre-service biology teachers dominantly thought about concepts related to "structures required for reproduction" in both techniques drew relevant figures and wrote explanations. In the category of "structures required for reproduction", they talked mostly about "sperm" and "egg", and presented relevant drawings. Table 4 shows examples from what the pre-service teachers drew on the concept of reproduction.

On the other hand, analyses pertaining to the drawings of the pre-service biology teachers on reproduction are presented in Table 5 under the following relevant levels: non-representative drawings (30), drawings with alternative conceptions (11), partial drawings (2) and conceptual representative drawings (2). In determining these levels, the data were grouped from level 1 to level 5 (Bahar et al., 2008; Bartoszeck, Machado, \& Amann-Gainotti, 2008; Cinici, 2013; Reiss \& Tunnicliffe, 2001). In this framework, non-representative drawings fell under a total 4 categories (structures required for reproduction, insemination, types of reproduction, and reproduction and inheritance); drawings with alternative conceptions fell under 6 categories (structures required for reproduction, insemination, reproduction and inheritance, defining reproduction, reproductive anatomy and types of reproduction); partial drawings fell under 4 categories (structures required for reproduction, types of reproduction, insemination, and defining reproduction); and conceptual representative drawings fell under 2 categories (reproduction in plants and sections, and types of reproduction).

As Table 5 shows, there is no participant at level 1 who did not draw anything on the concept of reproduction. It was determined that 28 participants provided non-representative drawings at level 2, 9 participants presented drawings with alternative conceptions at level 3, 5 participants at level 4 presented partial drawings, and 2 participants at level 5 presented conceptual representative drawings. This shows that $3 / 4$ of the participants expressed their cognitive structures about reproduction through non-representative drawings. When 9 other participants who presented drawings with alternative conceptions are added to this percentage, it appears that a very high percentage of the participant pre-service Biology teachers expressed their cognitive structures about reproduction through non-representative drawings and drawings that include alternative conceptions. It means that they explained the subject with simple, vague and non-scientific drawings without thinking about the subject in length and breadth. Therefore, it is concluded that they express conceptual structures with personalized figures, and that their academic cognitive structures are insufficient. It was observed that these drawings were mostly concentrated on the category of "structures required for reproduction", and that their conceptual representative drawings, which were on the subject of reproduction in plants, were almost nonexistent.

\section{Pre-Service Biology Teachers’ Alternative Conceptions of Reproduction}

Below, analyses of alternative conceptions presented by the participants about the concept of reproduction are presented with respect to assessment instruments.

Participants' explanations regarding the category of " $\mathrm{de}$ fining reproduction";

Example from the independent word association test;

"...Reproduction is not an obligation for living beings" (P35). Reproduction is obligatory for living beings in order for them to maintain their existence. It was determined that the participant had imperfect and incorrect knowledge.

Participants' explanations regarding the category of "insemination";

Example from the drawing-writing technique;

"...living beings emerge as a result of consecutive mitotic divisions of a zygote" (P13).

Participants' explanations regarding the category of " $\mathrm{de}$ fining reproduction and its importance";

Example from the drawing-writing technique;

"The male has a sexual intercourse with the female and a then they have a child" (P8).

"It is the forming of a new individual through the combination of male and female reproductive cells under appropriate conditions" (P17).

"Zygote is produced as a result of the fertilization of egg (female reproductive cell) and sperm (male reproductive cell)..." (P14; P15).

"Zygote is produced as a result of the fertilization of the egg cell with $n$ chromosome and the sperm cell..." (P13). 
Table 3.

Findings related to categories and sub-categories obtained using drawing-writing technique.

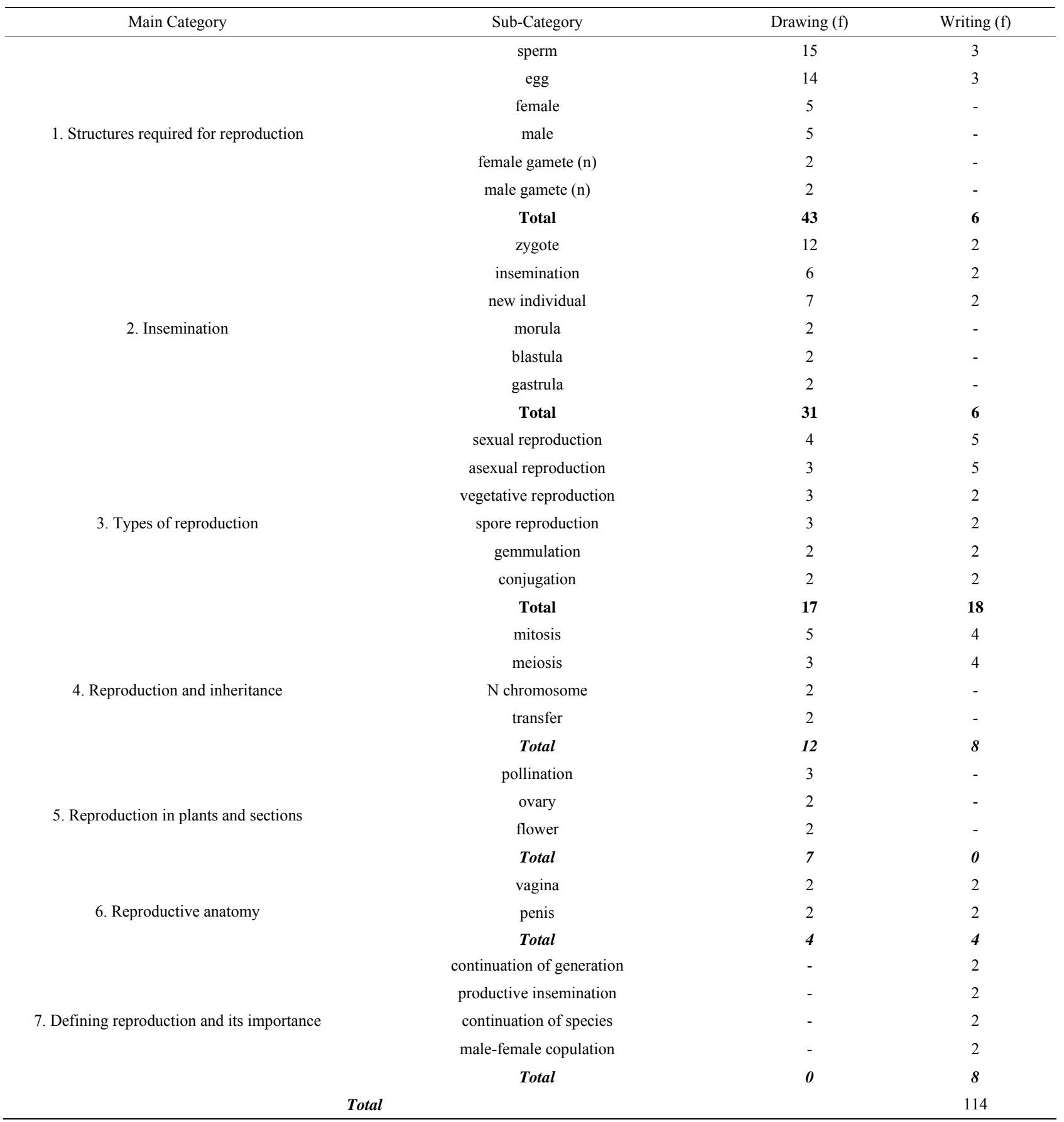

It was determined, based on the examples presented above, that the pre-service biology teachers had imperfect and incurrect knowledge in the categories of "defining reproduction, insemination, and defining reproduction and its importance". It was also observed that some participants fail to write proper sentences, whereas some others fail to turn their sentences into meaningful ones. This finding might have stemmed from the participants' insufficient cognitive structures or their problems in expressing what they know. When all the data presented above are evaluated together, it is concluded that the pre-ser- vice teachers' cognitive structures about reproduction fall under certain categories. Assessing these data, the model about the cognitive structures of pre-service biology teachers on the subject of reproduction was produced (Figure 1). According to the analysis results, while 6 categories were defined in the independent word association test regarding the participants' cognitive structures about reproduction, 6 categories were also defined in the drawing-writing technique. As is seen in the Figure 1, the cognitive structures of the participants about the concept of reproduction emerged in relation to a total of 7 categories. 
Table 4.

Examples obtained through drawing-writing technique on the concept of reproduction.

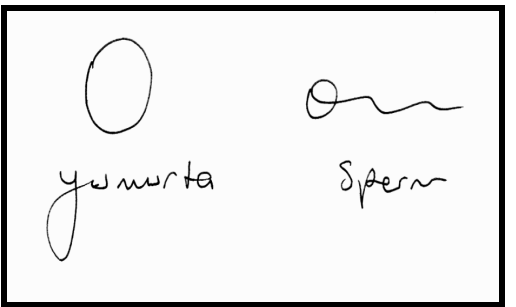

1. Category: Structures required for reproduction, $P 12$

The participant drawing (P12) depicting which Structures required for reproduction is.

The participant mentions, "egg and sperm".

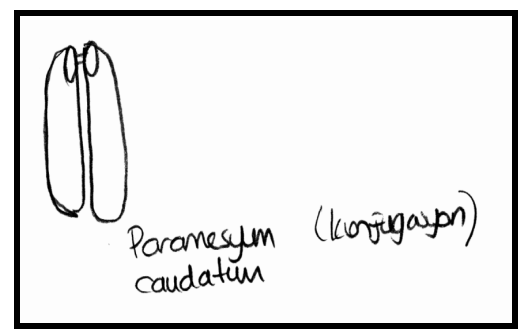

3. Category: Types of reproduction, $P 5$

The participant drawing (P5) depicting how types of reproduction are.

The participant mentions, "conjugation and paramecium".

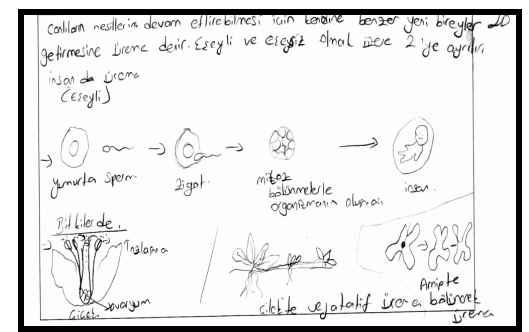

5. Category: Reproduction in plants and sections, $P 20$

The participant drawing ( $\mathrm{P} 20)$ depicting how reproduction in plants and sections are.

The participant mentions, "The male has a sexual intercourse with the female and a then they have a child.

Reproduction refers to living beings' production of new similar individuals in order to maintain their species. It is divided into two: sexual and asexual. Reproduction in humans, reproduction in amoebas, vegetative reproduction, reproduction in plants through pollination".

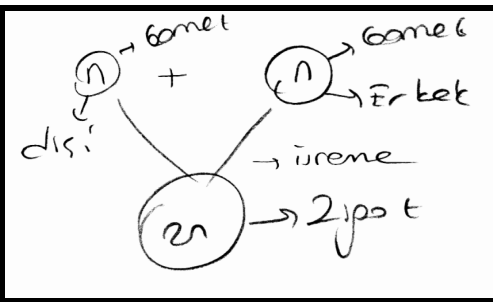

2. Category: insemination, $\mathrm{P} 7$

The participant drawing (P7) depicting how zygote is. The participant mentions, "zygote, male, female, reproduction and gamete".

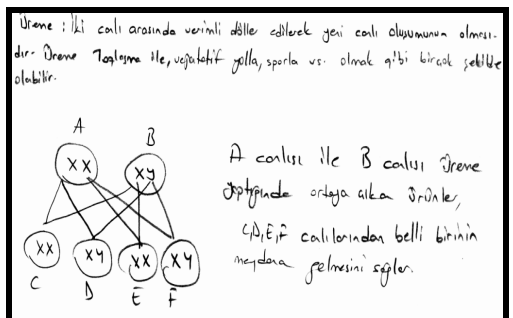

4. Category: Reproduction and inheritance, $P 22$

The participant drawing (P22) depicting how reproduction and inheritance are.

The participant mentions, "Reproduction: Formation of a new living being as a result of productive fertilization between two living beings. It occurs in many ways such as pollination, vegetation or spore.

When the living being $\mathrm{A}$ and the living being $\mathrm{B}$ copulate, the outcomes produce one of living beings $\mathrm{C}, \mathrm{D}, \mathrm{E}$ or F".

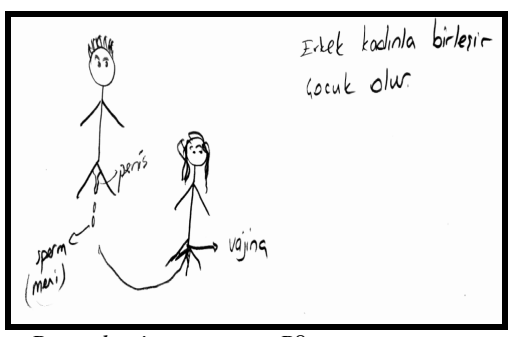

6. Category: Reproductive anatomy, $P 8$

The participant drawing (P8) depicting how Reproductive anatomy is. The participant mentions, "The male has a sexual intercourse with the female and a then they have a child. Vagina, penis, sperm".
On the other hand, it was determined that alternative conceptions fell under a total of 3 categories.

\section{Conclusion and Discussion}

In this study, which was aimed at determining pre-service biology teachers' cognitive structures on the concept of reproduction; ample data that support, explain and detail one another were obtained both through the independent word association test and the drawing-writing technique.

The responses given in the independent word association test were grouped under the following 6 categories: "structures required for reproduction", "reproduction in plants and sections", "types of reproduction", "insemination", "reproduction-inheritance", and "defining reproduction and its importance". On the other hand, the drawing-writing technique produced the following 7 categories: "structures required for reproduction", "insemination", "types of reproduction", "reproduction-inheritance", "reproduction in plants and sections", "reproductive anatomy" and "defining reproduction and its importance". These findings show that detailed data can be collected on the conceptual structure of the same subject by 
Table 5.

Analyses of drawings on reproduction.

\begin{tabular}{c}
\hline Levels \\
Level 1. \\
No Drawing \\
$\begin{array}{c}\text { Level 2. } \\
\text { Non-Representative } \\
\text { Drawings } \\
\text { (n=28) }\end{array}$
\end{tabular}

The participant drawing (P2) depicting how reproduction occurs is.

The participant mentions, "Reproduction occurs when the male and female reproductive cells come together to produce a fertile semen".

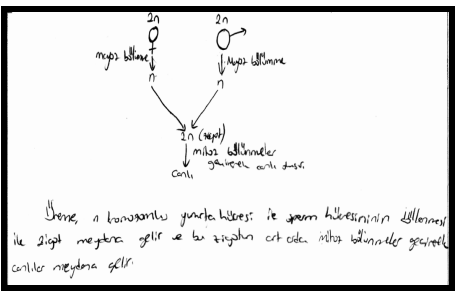

The participant drawing (P13) depicting how reproduction occurs is.

The participant mentions, "The living being is formed by undergoing mitotic divisions. Zygote emerges as the egg cell with $\mathrm{n}$ chromosome and the sperm cell are matched, and the organism emerges as a result of this zygote's consecutive mitotic divisions".

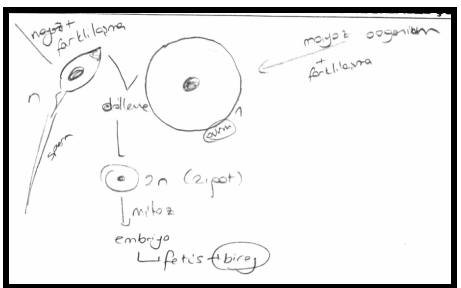

The participant drawing (P10) depicting how reproduction occurs is.

The participant mentions, "meiosis, mitosis, division, zygote, fetus, sperm, egg, insemination. Sperm + egg = insemination, zygote, embryo, fetus".

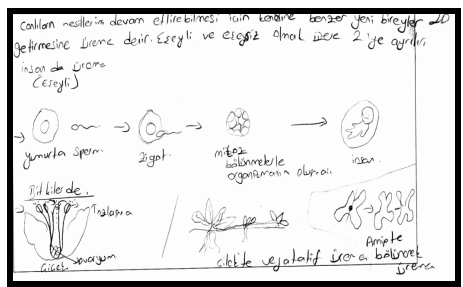

Conceptua Representative Drawings $(\mathrm{n}=2)$

The participant drawing (P20) depicting how reproduction occurs is.
Drawing Examples

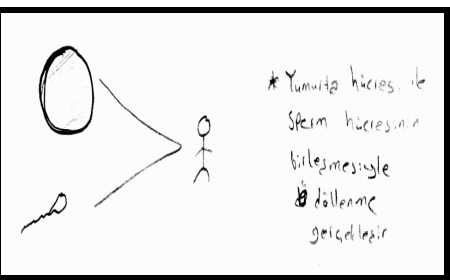

The participant drawing (P31) depicting how fertilization occurs is The participant mentions, "Fertilization occurs with the copulation of egg and sperm cells".

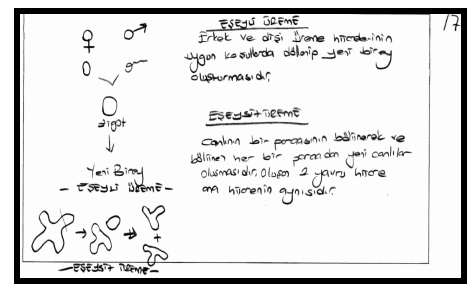

The participant drawing (P17) depicting how reproduction occurs is. The participant mentions, Sexual reproduction: It is the forming of a new individual through the combination of male and female reproductive cells under appropriate conditions. Asexual reproduction: Separation of a part from an organism, and formation of a new living being from that part. These two daughter cells are the same as the mother cell.

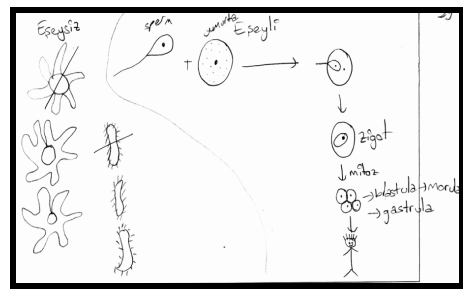

The participant drawing (P29) depicting how reproduction occurs is. The participant mentions, "sexual reproduction, asexual reproduction, zygote, sperm, egg, morula, gastrula. Sexual, asexual = sperm + egg (sexual reproduction $=$ zygote $\ldots$ mitosis ...blastula, morula, gastrula"

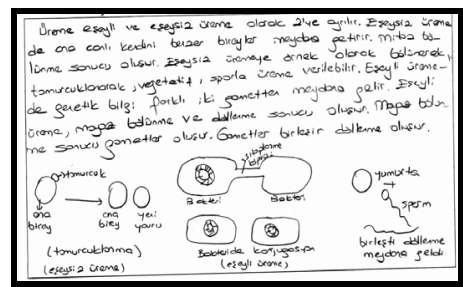

The participant mentions, "Reproduction refers to living beings' production of new similar individuals in order to maintain their species. It is divided into two: sexual and asexual. Reproduction in humans, reproduction in amoebas, vegetative reproduction,

reproduction in plants through pollination. Sperm + egg

= insemination, zygote, embryo, fetus".
The participant drawing (P32) depicting how reproduction occurs is. The participant mentions, "meiosis, mitosis, division, zygote, fetus, sperm, egg, insemination. Reproduction occurs sexually or asexually. In asexual one, the mother organism produces similar living beings. It occurs as a result of mitotic division.

Examples are pollination, division, vegetative and spore reproduction. In sexual reproduction, genetic data consists of two different gametes. It occurs as a result of meiotic division and fertilization. Gametes are produced as a result of meiotic division. They copulate and fertilization takes place", 
using different assessment instruments that support one another. Therefore, this research demonstrates that ample data can be obtained by using different assessment instruments. Therefore, the process of data diversification was executed in order to ensure the validity and reliability of this qualitative research, and the requirement of using different but supportive assessment instruments for cognitive structure researches was satisfied. In both assessment instruments, the categories of "structures required for reproduction" and "types of reproduction" emerged as common and dominant categories.

The findings suggest that the cognitive structures of the participant pre-service biology teachers on the subject of reproduction are not sufficient, and that they have imperfect and incurrect knowledge; as they mostly presented associations in the form of definitions about, for example, structures required for reproduction, types of reproduction, defining reproduction and explaining its importance. However, reproduction is a very comprehensive subject, which pertains to all living beings across biological systems, which differs by organisms, and which requires micro- and macro-level associations. The concept is also linked with numerous other subjects such as growth, development, hormones, Mendel genetics, genes, chromosomes, mitotic and meiotic division, and so forth (Krawczyk, 2007; Sinan \& Karadeniz, 2010; Wynne, Stewart \& Passmore, 2001). Therefore, it was observed that the participant pre-service boilogy teachers failed to construct associations related to the details of the concept of reproduction and to express concepts at an advanced cognitive level.

On the other hand, alternative conceptions of the participants were also determined using both assessment instruments. It was determined that some participants, in the category of "defining reproduction" that requires basic knowledge, focused mostly on the reproduction of human beings and have imperfect and incorrect knowledge such as; "...Reproduction is not an obligetion for living beings", "The male has a sexual intercourse with the female and a then they have a child", "It is the forming of a new individual through the combination of male and female reproductive cells under appropriate conditions", "Zygote is produced as a result of the fertilization of the egg cell with $n$ chromosome and the sperm cell". This finding is further supported by the fact that the participants presented non-representative drawings at the level 2 and drawings with alternative conceptions at the level 3 . The relevant literature similarly indicates that students from different educational levels have imperfect and incorrect knowledge on the subject of defining-explaining reproduction. Sesli and Kara (2012) determined that pre-service biology teachers mostly offered simple and shallow explanations, and in general, they do not see reproduction as a common characteristic among living beings, they see it as the copulation of male and female, they define reproduction only as fertilization, and they do not understand the reproductive mechanism, its operation and synthesis mechanisms.

The literature is mostly in parallel with the findings of this research. In the literature, it has been determined that participants had incompetence and alternative conceptions about the following: chromosome, gene, meiotic division, mutation, mitotic division, modification, DNA (Akyurek \& Afacan, 2012; Aydin \& Balim, 2013), genetic material and physical connection between chromosomes, continuity of genetic materials both among and within organisms, relationship between the behaviors of chromosomes in cell division (Lewis et al., 2000a), genetic transfer of knowledge and genes, chromosomes and cel- lular structures (Robinson \& Lewis, 2000), continuity of genetic knowledge for single-cell organisms and genes (Lewis et al., 2000b, 2000c), cell division (Emre \& Bahsi, 2006), allele, homologous chromosome, replicated chromosome, chromosome number and DNA strand, (Tekkaya et al., 2000), genetic technology (Franke, Scharfenberg \& Bogner, 2013), chromosome-DNA relationship, chromosome structure of cells that emerge as a result of mitotic and meiotic division, diploid-haploid cells, number of cells that emerge as a result of meiotic and mitotic division, sister chromatids, instances in mitotic and meiotic division (Atilboz, 2004).

It is also suggested, in studies on reproduction in plants, that insufficiencies are widespread both in course books (Schussler, 2008) and participants, and that participants have alternative conceptions (Bebbington, 2005; Hershey, 2004; Mak et al., 1999).

In conclusion, findings of this study and of studies carried out earlier suggest that participants from all academic levels have imperfect cognitive structures about the concept of reproduction. This finding was obtained in this research using different assessment instruments. The finding that pre-service Biology teachers, who are future Biology teachers, have imperfect cognitive structures about the concept of reproduction is of high importance and it needs to be addressed with attention. For teachers may transmit their cognitive insufficiencies to their students and cause them to learn incorrectly.

\section{Suggestions}

Suggestions related to Education-Teaching Activities: It is already known that students struggle to form their cognitive structures about biological systems (Cimer, 2012; Hmelo-Silver \& Azevedo, 2006; Krawczyk, 2007; Lukin, 2013; Prokop et al., 2007; Sinan \& Karadeniz, 2010; Wynne, Stewart, \& Passmore, 2001), and reproduction is among the most important concepts under this category. The art of teaching science needs to be reshaped in order to accomplish a positive transformation in this regard and to overcome students' above-mentioned struggles (Gilbert et al., 1998a, 1998b; Schnotz \& Preuß, 1997). It has been widely accepted that the quality of instruction plays a key role in students' learning outcomes (Kuijpers, Houtveen, \& Wubbels, 2010; Ugwu \& Soyibo, 2004). In this respect, teaching practices, which allow students to learn by carrying out laboratory applications, in which concepts are visualized in printed materials, in which abstract concepts are concretized, and in which students can learn by relating concepts to their daily lives, should be given priority. It would be further useful to benefit from technology in this process by offering computer-aided and/or simulated teaching.

Beginning from the elementary school, students' alternative conceptions should be determined and eliminated, because they bring along these alternative conceptions to subsequent academic levels and they negatively affect their cognitive structures. The alternative conceptions found in this research might have been developed in grade levels prior to university.

Teachers should help students accurately construct their cognitive structures by enabling them to become aware of their own cognitive strategies and learning styles.

Biology curricula should be developed in a practice-oriented way in which students can correctly construct their cognitive structures about concepts.

It should always be kept in mind at all levels of education 
that pre-service teachers should be provided with a quality education so that they can do so with their future students.

In teaching the invisible abstract concepts, drawings may be included intensively in every education level for the development of visual images of students. Thus, students' cognitive structures can be formed as more powerful.

Appropriate course contents may be incorporated into the teacher education programs to gain biological literacy and associative thinking skills with daily life. Thus, students may be more interested in courses; their learning may be facilitated because they could find answers to the biological, social and individual questions that they are curious about.

Suggestions to future studies: such researches might be experimental or they might use other techniques such as two-stage multiple-choice tests, drawings, interviews, independent word association test, structured grid, diagnostic tree, concept maps, conceptual change texts, analogy or prediction-observation-explanation.

\section{REFERENCES}

Ad, V. N. K., \& Demirci, N. (2012). Prospective teachers' levels of associating environmental problems with science fields and thermodynamics laws. Ahi Evran University Journal of Kirsehir Educatioan Faculty, 13, 19-46.

Ainsworth, S., Prain, V., \& Tytler, R. (2011). Drawing to learn in science. Science Education, 333, 1096-1097.

Akyurek, E., \& Afacan, O. (2012). Determining the 8th grade students' misconceptions in the unit of "cell division" by using roundhouse diagramming. International Journal of Curriculum and Instructional Studies, 2, 47-58.

Albanese, A., \& Vicentini, M. (1997). Why do we believe that an atom is colorless? Reflections about the teaching of the particle model. Science \& Education, 6, 251-261. doi:10.1023/A:1017933500475

Amuyunzu-Nyamongo, M., Biddlecom, A. E., Ouedraogo, C., \& Woog, V. (2005). Qualitative evidence on adolescents' views of sexual and reproductive health in sub-Saharan Africa. Occasional Report No. 16. New York: The Alan Guttmacher Institute.

Atasoy, B. (2004). Science learning and teaching. Ankara: Asil Publisher.

Atilboz, N. G. (2004). 9th Grade students' understanding levels and misconceptions about mitosis and meiosis. Gazi University Journal of Gazi Educational Faculty (GUJGEF), 24, 147-157.

Aydin, G., \& Balim, A. G. (2013). Students' misconceptions related to subjects of "cell division and heredity". Journal of Research in Education and Teaching, 2, 338-348.

Backett-Milburn, K., \& McKie, L. (1999). A critical appraisal of the draw and write technique. Health Education Research Theory \& Practice, 14, 387-398. doi:10.1093/her/14.3.387

Bahar, M., Johnstone, A. H., \& Hansell, M. H. (1999). Revisiting learning difficulties in biology. Journal of Biological Education, 33, 84-86. doi:10.1080/00219266.1999.9655648

Bahar, M., Johnstone, A. H., \& Sutcliffe, R. G. (1999). Investigation of students' cognitive structure in elementary genetics through word association tests. Journal of Biological Education, 33, 134-141. doi:10.1080/00219266.1999.9655653

Bahar, M., \& Kilicli, F. (2001). Investigating the bonds between the principles of Ataturk through the method of word association test. $X$. National Congress of Educational Sciences, Turkey.

Bahar, M. (2003). Misconceptions in biology education and conceptual change strategies. Educational Sciences: Theory \& Practice, 3, 5564 .

Bahar, M., \& Ozatli, N. S. (2003). Investigating high school freshman students' cognitive structures about the basic components of living things through word association test method. Journal of the Institute of Science and Technology of Balikesir University, 5, 75-85.

Bahar, M., Nartgun, Z., Durmus, S., \& Bicak, B. (2006). Traditional and alternative assessment and evaluation of teachers' manual. Ankara: Pegem A Publishing.

Bahar, M., Ozel, M., Prokop, P., \& Usak, M. (2008). Science student teachers' ideas of the heart. Journal of Baltic Science Education, 7, 1648-3898.

Bartoszeck, A. B., Machado, D. Z., \& Amann-Gainotti, M. (2008). Representations of internal body image: A study of preadolescents and adolescent students in Araucaria, Paraná, Brazil. Ciências \& Cognição, 13, 139-159.

Bebbington, A. (2005). The ability of A-level students to name plants. Journal of Biological Education, 39, 63-67. doi: $10.1080 / 00219266.2005 .9655963$

Cardellini, L., \& Bahar, M. (2000). Monitoring the learning of chemistry through word association tests. Australian Chemistry Research Book, 19, 59-69.

Cetin, G., Ozarslan, M., Isik, E., \& Eser, H. (2013). Students' views about health concept by drawing and writing technique. Energy Education Science and Technology, 5, 597-606.

Cimer, A. (2012). What makes biology learning difficult and effective: Students' views? Educational Research and Reviews, 7, 61-71.

Cinici, A. (2013). From caterpillar to butterfly: A window for looking into students' ideas about life cycle and life forms of insects. Journal of Biological Education, 47, 84-95. doi:10.1080/00219266.2013.773361

Chi, M. T., Slotta, J. D., \& Leeuw, N. (1994). From things to processes: A theory of conceptual change for learning science concepts. Learning and Instruction, 4, 27-43. doi:10.1016/0959-4752(94)90017-5

Cohen, L., \& Manion, L. (1997). Research methods in education. London: Routledge.

CUSE (Committee on Undergraduate Science Education) (1997). Misconceptions as barriers to understanding science. Science Teaching Reconsidered: A Handbook. Washington DC: National Academy Press.

Dagher, Z. R. (1994). Does the use of analogies contribute to conceptual change? Science Education, 78, 601-614. doi: $10.1002 /$ sce. 3730780605

Daskolia, M., Flogaitis, E., \& Papageorgiou, E. (2006). Kindergarten teachers' conceptual framework on the ozone layer depletion. Exploring the associative meanings of a global environmental issue. Journal of Science Education and Technology, 15, 168-178. doi:10.1007/s10956-006-9004-8

Daymon, C., \& Holloway, I. (2003). Qualitative research methods in public relations and marketing communications. London: Rout ledge.

diSessa, A., \& Sherin, B. L. (1998). What change in conceptual change? International Journal of Science Education, 2, 1155-1198. doi: $10.1080 / 0950069980201002$

Doran, R. L. (1972). Misconception of selected science concepts held by elementary school students. Journal of Research in Science Teaching, 9, 127-137. doi:10.1002/tea.3660090204

Dove, J. E., Everett, L. A., \& Preece, P. F. W. (1999). Exploring a hydrological concept though children's drawings. International Journal of Science Education, 21, 485-497. doi:10.1080/095006999290534

Driver, R. (1989). Students' conceptions and the learning of science. International Journal of Science Education, 11, 481-490. doi: $10.1080 / 0950069890110501$

Driver, R., \& Easley, J. (1978). Pupils and paradigms: A review of literature related to concept development in adolescent science students. Studies in Science Education, 5, 61-84. doi: 10.1080/03057267808559857

Duit, R., Roth, W.-M., Komarek, M., \& Wilbers, T. (1998). Conceptual change cum discourse analysis to understand cognition in a unit on chaotic systems: Towards an integrative perspective on learning in science. International Journal of Science Education, 20, 1059-1073. doi:10.1080/0950069980200904

Emre, I., \& Bahsi, M. (2006). Misconceptions of science teacher candidates about cell division. Eastern Anatolia Region Research Journal (DAUM), 4, 70-73.

Ercan, F., Tasdere, A., \& Ercan, N. (2010). Observation of cognitive 
structure and conceptual changes through word associations tests. Journal of Turkish Science Education, 7, 138-154.

Franco, C., Lins, H., Colinvaux, D., Krapas, S., Queiroz, G., \& Alves, F. (1999). From scientist's and inventors' minds to some scientific and technological products: Relationships among theories, models, mental models and conceptions. International Journal Science Education, 21, 277-281. doi:10.1080/095006999290705

Franke, G., Scharfenberg, F.-J., \& Bogner, F. X. (2013). Investigation of students' alternative conceptions of terms and processes of gene technology. Hindawi Publishing Corporation ISRN Education, 2013, Article ID: 741807. doi:10.1155/2013/741807

Gall, M. D., Borg, W. R., \& Gall, J. P. (2002). Educational research: An introduction (7th ed.). White Plains, New York: Pearson/Allyn \& Bacon.

Gilbert, J. K., Boulter, C., \& Rutherford, M. (1998a). Models in explanations, part 1: Horses for courses? International Journal of Science Education, 20, 83-97. doi:10.1080/0950069980200106

Gilbert, J. K., Boulter, C., \& Rutherford, M. (1998b). Models in explanations, part 2: Whose voice? Whose ears? International Journal of Science Education, 20, 187-203. doi:10.1080/0950069980200205

Gilbert, J. K., \& Boulter, C. J. (2000). Learning science through models and modeling. In K. Tobin and B. Frazer (Eds.), The international handbook of science education (pp. 53-66). Dordrecht: Kluwer.

Given, L. M. (2008). The sage encyclopedia of qualitative research methods. Thousand Oaks, CA: Sage.

Gussarsky, E., \& Gorodetsky, M. (1990). On the concept "Chemical equilibrium": The associative framework. Journal of Research in Science Teaching, 27, 197-204. doi:10.1002/tea.3660270303

Hershey, D. R. (2004). Avoid misconceptions when teaching about plants. http://www.actionbioscience.org/education/hershey.html

Hitchcock, G., \& Hughes, D. (1995). Research and the teacher (2nd ed.). London: Routledge.

Hmelo-Silver, C. E., \& Azevedo, R. (2006). Understanding complex systems: Some core challenges. The Journal of the Learning Sciences, 15, 53-61. doi:10.1207/s15327809j1s1501 7

Hovardas, T., \& Korfiatis, K. J. (2006). Word associations as a tool for assessing conceptual change in science education. Learning and Instruction, 16, 416-432. doi:10.1016/j.learninstruc.2006.09.003

Hruschka, D. J., Schwartz, D., St. John, D. C., Picone-Decaro, E., Jenkins, R. A., \& Carey, J. W. (2004). Reliability in coding open-ended data: Lessons learned from HIV behavioral research. Field Methods, 16, 307-331. doi:10.1177/1525822X04266540

Iliyasu, Z., Aliyu, M. H., Abubakar, I. S., \& Galadanci, H. S. (2012). Sexual and reproductive health communication between mothers and their adolescent daughters in Northern Nigeria. Health Care for Women International, 33, 138-152. doi:10.1080/07399332.2011.562996

Inagaki, K., \& Hatano, G. (2002). Young children's naïve thinking about the biological world (Essays in Developmental Psychology). NY: Psychology Press-Taylor and Francis Group.

Inagaki, K., \& Hatano, G. (2006). Young children's conception of the biological world. Current Directions in Psychological Science, 15, 177-181. doi:10.1111/j.1467-8721.2006.00431.x

Isikli, M., Tasdere, A., \& Goz, N. L. (2011). Investigation teacher candidates' cognitive structure about principles of Ataturk through word association test. Usak University Journal of Social Science, 4, 50-72.

Jones, M. G., \& Rua, M. J. (2006). Conceptual representations of flu and microbial illness held by students, teachers, and medical professsionals. School Science and Mathematics, 108, 263-278. doi:10.1111/j.1949-8594.2008.tb17836.x

Knight, S. L., Nolan, J., Lloyd, G., Arbaugh, F., Edmondson, J., \& Whitney, A. (2013). Quality teacher education research: How do we know it when we see it? Journal of Teacher Education, 64, 114-116. doi:10.1177/0022487112469941

Knippels, M. C. P. J., Waarlo, A. J., \& Boersma, K. T. (2005). Design criteria for learning and teaching genetics. Journal of Biological Education, 39, 108-112. doi:10.1080/00219266.2005.9655976

Kose, S. (2008). Diagnosing student misconceptions: Using drawings as a research method. World Applied Sciences Journal, 3, 283-293.

Koseoglu, F., \& Bayir, E. (2011). Examining cognitive structures of chemistry teacher candidates about gravimetric analysis through word association test method. Trakya University Educational Faculty Journal, 1, 107-125.

Kostova, Z., \& Radoynovska, B. (2008). Word association test for studying conceptual structures of teachers and students. Bulgarian Journal of Science and Education Policy, 2, 209-231.

Kostova, Z., \& Radoynovska, B. (2010). Motivating students' learning using word association test and concept maps. Bulgarian Journal of Science and Education Policy, 4, 62-98.

Krawczyk, T. D. (2007). Using problem-based learning and hands on activities to teach meiosis and heredity in a high school biology classroom. Master of Science, East Lansing, MI: Michigan State University.

Kuijpers, J. M., Houtveen, A. A. M., \& Wubbels, T. (2010). An integrated professional development model for effective teaching. Teaching and Teacher Education, 26, 1687-1694.

Kurt, H. (2013). Biology student teachers' cognitive structure about "living thing". Educational Research and Reviews, 8, 871-880.

Kus, E. (2003). Quantitative-qualitative research techniques. Ankara: Ani Publishing.

Lazarowitz, R., \& Penso, S. (1992). High school students' difficulties in learning biology concepts. Journal of Biological Education, 26, 215-224. doi:10.1080/00219266.1992.9655276

Lewis, J., Leach, J., \& Wood-Robinson, C. (2000a). Chromosomes: The missing link-Young people's understanding of mitosis, meiosis, and fertilization. Journal of Biological Education, 34, 189-199. doi: $10.1080 / 00219266.2000 .9655717$

Lewis, J., Leach, J., \& Wood-Robinson, C. (2000b). All in the genes? -Young people's understanding of the nature of genes. Journal of Biological Education, 34, 74-79.

doi: $10.1080 / 00219266.2000 .9655689$

Lewis, J., Leach, J., \& Wood-Robinson, C. (2000c). What's in a cell? -Young people's understanding of the genetic relationship between cells, within an individual. Journal of Biological Education, 34, 129132. doi: $10.1080 / 00219266.2000 .9655702$

Lukin, K. (2013). Exciting middle and high school students about immunology: An easy, inquiry-based lesson. Immunologic Research, 55, 201-209. doi:10.1007/s12026-012-8363-x

Mak, S. Y., Yip, D. Y., \& Chung, C. M. (1999). Alternative conceptions in biology related topics of integrated science teachers and implications for teacher education. Journal of Science Education and Technology, 8, 161-170. doi:10.1023/A:1018617202155

Mike, M., \& Treagust, D. F. (1998). A pencil and paper instrument to diagnose students' conceptions of breathing, gas exchange and respiration. Australian Science Teachers Journal, 44, 55-60.

Miles, M. B., \& Huberman, A. M. (1994). Qualitative data analysis: An expanded sourcebook (2nd ed.). Thousand Oaks, CA: Sage.

Nyachwayaa, J. M., Mohameda, A.-R., Roehriga, G. H., Woodb, N. B., Kernc, A. L., \& Schneiderd, J. L. (2011). The development of an open-ended drawing tool: An alternative diagnostic tool for assessing students' understanding of the particulate nature of matter. Chemistry Education Research and Practice, 12, 121-132. doi:10.1039/c1rp90017j

Odom, A. L., \& Barrow, L. H. (1995). Development and application of a two-tier diagnostic test measuring college biology students' understanding of diffusion and osmosis after a course of instruction. Journal of Research in Science Teaching, 32, 45-61. doi:10.1002/tea.3660320106

Quinn, F., Pegg, J., \& Panizzon, D. (2009). First-year biology students' understandings of meiosis: An investigation using a structural theoretical framework. International Journal of Science Education, 31, 1279-1305. doi:10.1080/09500690801914965

Patrick, P. G., \& Tunnicliffe, S. D. (2010). Science teachers' drawings of what is inside the human body. Journal of Biological Education, 44, 81-87. doi:10.1080/00219266.2010.9656198

Patton, M. Q. (1990). Qualitative evaluation and research methods. Thousand Oaks, CA: Sage.

Pluhar, Z. F., Piko, B. F., Kovacs, S., \& Uzzoli, A. (2009). "Air pollution is bad for my health": Hungarian children's knowledge of the role of environment in health and disease. Health \& Place, 15, 239 - 
246. doi:10.1016/j.healthplace.2008.05.005

Pines, A., \& West, L. (1986). Conceptual understanding and science learning: An interpretation of research within sources-of knowledge framework. Science Education, 70, 583-604.

doi:10.1002/sce.3730700510

Posner, G., Strike, K., Hewson, P., \& Gertzog, W. (1982). Accommodation of a scientific conception: Toward a theory of conceptual change. Science Education, 66, 211-227.

doi: $10.1002 /$ sce. 3730660207

Pridmore, P., \& Bendelow, G. (1995). Images of health: Exploring beliefs of children using the 'draw-and-write' technique. Health Education Journal, 54, 473-488. doi: $10.1177 / 001789699505400410$

Prokop, P., Prokop, M., \& Tunnicliffe, S. D. (2007). Effects of keeping animals as pets on children's concepts of vertebrates and invertebrates. International Journal of Science Education, 30, 431-449. doi:10.1080/09500690701206686

Prokop, P., Prokop, M., Tunnicliffe, S. D., \& Diran, C. (2007). Children's ideas of animals' internal structures. Journal of Biological Education, 41, 62-67. doi:10.1080/00219266.2007.9656064

Prokop, P., Fancóvicóva, J., \& Tunnicliffe, S. D. (2009). The effect of type of instruction on expression of children's knowledge: How do children see the endocrine and urinary system? International Journal of Environmental \& Science Education, 4, 75-93.

Punch, K. F. (2005). Introduction to social research: Quantitative \& qualitative approaches. London: Sage.

Reiss, M. J., \& Tunnicliffe, S. D. (2001). Students' understandings of human organs and organ systems. Research in Science Education, 31, 383-399. doi:10.1023/A:1013116228261

Reiss, M. J., Tunnicliffe, S. D., Andersen, A. M., Bartoszeck, A., Carvalho, G. S., Chen, S.-Y., Jarman, R., et al. (2002). An international study of young peoples' drawings of what is inside themselves. Journal of Biological Education, 36, 58-64. doi:10.1080/00219266.2002.9655802

Rennie, L. J., \& Jarvis, T. (1995). English and Australian children's perceptions about technology. Research in Science \& Technological Education, 13, 37-52. doi:10.1080/0263514950130104

Roberts, P., \& Priest, H. (2006). Reliability and validity in research. Nursing Standard, 20, 41-45.

Robinson, C. W., \& Lewis, J. (2000). Genes, chromosomes, cell division \& inheritance-Do students see any relationship? International Journal of Science Education, 22, 177-195. doi: 10.1080/095006900289949

Sato, M., \& James, P. (1999). "Nature" and "environment" as perceived by university students and their supervisors. International Journal of Environmental Education and Information, 18, 165-172.

Schnotz, W., \& Preuß, A. (1997). Task-dependent construction of mental models as a basis for conceptual change. European Journal of Psychology of Education, 12, 185-211. doi:10.1007/BF03173084

Sesli, E., \& Kara, Y. (2012). Development and application of a two-tier multiple-choice diagnostic test for high school students' understanding of cell division and reproduction. Journal of Biological Education, 46, 214-225. doi:10.1080/00219266.2012.688849

Seymour, J., \& Longdon, B. (1991). Respiration-That's breathing isn't it? Journal of Biological Education, 23, 177-184. doi:10.1080/00219266.1991.9655203

Shavelson, R. J. (1974). Methods for examining representations of a subject-matter structure in a student's memory. Journal of Research in Science Teaching, 11, 231-249. doi:10.1002/tea.3660110307

She, H.-C. (2004). Facilitating changes in ninth grade students' understanding of dissolution and diffusion through DSLM instruction. Research in Science Education, 34, 503-525. doi:10.1007/s11165-004-3888-1

Shepardson, D. P., Wee, B., Priddy, M., \& Harbor, J. (2007). Students' mental models of the environment. Journal of Research in Science Teaching, 44, 327-348. doi:10.1002/tea.20161

Siegler, R. J. (1995). How does change occur: A micro genetic study on number conservation? Cognitive Psychology, 28, 225-273. doi:10.1006/cogp.1995.1006
Simpson, W. D., \& Marek, E. A. (1998). Understanding and misconceptions of biology concepts held by students attending small high schools and students attending large high schools. Journal of Research in Science Teaching, 25, 361-374. doi:10.1002/tea.3660250504

Sinan, O., \& Karadeniz, O. (2010). Teaching practice: Teaching the subject of mitosis for example, an activity. Elementary Education Online, 9, 1-7.

Skelly, K. M., \& Hall, D. (1993). The development and validation of a categorization of sources of misconceptions in chemistry. Paper presented at the Third International Seminar on Misconceptions and Educational Strategies in science and Mathematics, Ithaca.

Smith, M. (1991). Teaching cell division: Student difficulties and teaching recommendations. Journal of College Science Teaching, 21, 28-33.

Smith, E. L., Blakeslee, T. D., \& Anderson, C. W. (1993). Teaching strategies associated with conceptual change learning in science. Journal of Research in Science Teaching, 30, 111-126. doi:10.1002/tea.3660300202

Schussler, E. E. (2008). From flowers to fruits: How children's books represent plant reproduction. International Journal of Science Education, 30, 1677-1696. doi:10.1080/09500690701570248

Stafstrom, C, E., Rostasy, K., \& Minster, A. (2002). The usefulness of children's drawings in the diagnosis of headache. Pediatrics, 109, 460-472. doi:10.1542/peds. 109.3.460

Stavridou, H., \& Solomonidou, C. (1998). Conceptual reorganization and construction of the chemical reaction concept during secondary school. International Journal of Science Education, 20, 205-221. doi:10.1080/0950069980200206

Strommen, E. (1995). Lions and tigers and bears, Oh my! Children's conceptions of forests and their inhabitants. Journal of Research in Science Teaching, 32, 683-698. doi:10.1002/tea.3660320704

Udovic, D., Morris, D., Dickman, A., Postlethwait, J., \& Wetherwax, P. (2002). Workshop biology: Demonstrating the effectiveness of active learning in an introductory biology course. BioScience, 52, 272-281. doi:10.1641/0006-3568(2002)052[0272:WBDTEO]2.0.CO;2

Tekkaya, C., Ozkan, O., \& Sungur, S. (2001). Biology concepts perceived as difficult by Turkish high school students. Science Education, 66, 531-538.

Tekkaya, C. (2003). Remediating high school students' misconceptions concerning diffusion and osmosis through concept mapping and conceptual change text. Research in Science \& Technological Education, 21, 5-16. doi:10.1080/02635140308340

Tekkaya, C., Capa, Y., \& Yilmaz, O. (2000). Prospective teachers' misconceptions concerning general biology concepts. Hacettepe University Journal of Education, 18, 140-147.

Torkar, G., \& Bajd, B. (2006). Trainee teachers' ideas about endangered birds. Journal of Biological Education, 41, 5-8. doi:10.1080/00219266.2006.9656049

Treagust, D. F. (1988). Development and use of diagnostic tests to evaluate students' misconception in science. International Journal of Science Education, 10, 159-169. doi:10.1080/0950069880100204

Tsai, C.-C. (1999). Overcoming junior high school students' misconceptions about microscopic views of phase change: A study of an analogy activity. Journal of Science Education and Technology, 8, 83-91. doi:10.1023/A:1009485722628

Tsai, C.-C., \& Huang, C.-M. (2001). Development of cognitive structures and information processing strategies of elementary school students learning about biological reproduction. Journal of Biological Education, 36, 21-26. doi:10.1080/00219266.2001.9655791

Tsai, C. C., \& Huang, C.-M. (2002). Exploring students' cognitive structures in learning science: A review of relevant methods. Journal of Biological Education, 36, 163-169. doi: $10.1080 / 00219266.2002 .9655827$

Tyson, L. M., Venville, G. J., Harrison, G., \& Treagust, D. F. (1997). A multidimensional framework for interpreting conceptual change events in the classroom. Science Education, 81, 387-404. doi:10.1002/(SICI)1098-237X(199707)81:4<387::AID-SCE2>3.0.C $\mathrm{O} ; 2-8$

Ugoji, F. N. (2013). Investigating the reproductive health knowledge, 
self-concept and locus of control of students in Nigerian Universities. American International Journal of Social Science, 2, 45-53.

Ugwu, O., \& Soyibo, K. (2004). The effects of concept and vee mappings under three learning modes on Jamaican eighth graders' knowledge of nutrition and plant reproduction. Research in Science \& Technological Education, 22, 41-58. doi:10.1080/0263514042000187539

Verma, G. K., \& Mallick, K. (1999). Researching education: Perspectives and techniques. Philadelphia: Open University Press.

Vosniadou, S. (1996). Towards a revised cognitive psychology for new advances in learning and instruction. Learning and Instruction, 6, 95-109. doi:10.1016/0959-4752(96)00008-4

Vosniadou, S., \& Brewer, W. (1992). Mental models of the earth: A study of the conceptual change in childhood. Cognitive Psychology, 24, 535-585. doi:10.1016/0010-0285(92)90018-W

Vosniadou, S., \& Brewer, W. (1994a). Mental models of the day/night cycle. Cognitive Science, 18, 123-183. doi:10.1207/s15516709 cog1801_4

Vosniadou, S. (1994b). Capturing and modeling the process of concepttual change. Learning and Instruction, 4, 45-69. doi:10.1016/0959-4752(94)90018-3

Vygotsky, L. S. (1995b). Obras escogidas. Madrid: Visor.

Wagner, W., Valencia, J., \& Elejabarrieta, F. (1996). Relevance, discourse and the hot stable core of social representation-A structural analysis of word association. British Journal of Social Psychology, 35, 331-351. doi:10.1111/j.2044-8309.1996.tb01101.x

Wandersee, J. H., Mintzes, J. J., \& Novak, J. D. (1994). Research on alternative conceptions in science. In D. L. Gabel (Eds.), Handbook of research on science teaching and learning (pp. 177-210). New York: Simon \& Schuster and Prentice Hall International.

Warenius, L., Pettersson, K. O., Nissen, E., Höjer, B., Chishimba, P., \& Faxelid, E. (2007). Vulnerability and sexual and reproductive health among Zambian secondary school students. Culture, Health \& Sexuality: An International Journal for Research, Intervention and Care, 9, 533-544.

Wiersma, W., \& Jurs, S. G. (2005). Research methods in education: An introduction. Boston, MA: Ally and Bacon.

Wynne, C. F., Stewart, J., \& Passmore, C. (2001). High school students' use of meiosis when solving genetics problems. International Journal of Science Education, 23, 501-515.

White, R. T., \& Gunstone, R. F. (1992). Probing understanding. London: The Falmer Press.

Yayla, R. G., \& Eyceyurt, G. (2011). Mental models of pre-service science teachers about basic concepts in chemistry. Western Anatolia Journal of Educational Sciences, 2011, 285-294.

Yip, D. Y. (1998). Children's misconceptions on reproduction and implications for teaching. Journal of Biological Education, 33, 21-26. doi:10.1080/00219266.1998.9655632

Yorek, N., Sahin, M., \& Ugulu, I. (2010). Students' representations of the cell concept from 6 to 11 grades: Persistence of the "fried-egg model". International Journal of Physical Sciences, 5, 15-24.

Zoldosova, K., \& Prokop, P. (2007). Primary pupils' preconceptions about child prenatal development. Eurasia Journal of Mathematics, Science \& Technology Education, 3, 239-246. 